\title{
Review Article \\ Waste Material Adsorbents for Zinc Removal from Wastewater: A Comprehensive Review
}

\author{
Haider M. Zwain, ${ }^{1}$ Mohammadtaghi Vakili, ${ }^{2}$ and Irvan Dahlan ${ }^{3}$ \\ ${ }^{1}$ School of Civil Engineering, Universiti Sains Malaysia, Engineering Campus, Seri Ampangan, \\ 14300 Nibong Tebal, Pulau Pinang, Malaysia \\ ${ }^{2}$ School of Industrial Technology, Universiti Sains Malaysia, 11800 Penang, Malaysia \\ ${ }^{3}$ School of Chemical Engineering, Universiti Sains Malaysia, Engineering Campus, Seri Ampangan, \\ 14300 Nibong Tebal, Pulau Pinang, Malaysia \\ Correspondence should be addressed to Irvan Dahlan; chirvan@usm.my
}

Received 24 February 2014; Revised 5 June 2014; Accepted 6 June 2014; Published 24 June 2014

Academic Editor: Iftekhar A. Karimi

Copyright (C) 2014 Haider M. Zwain et al. This is an open access article distributed under the Creative Commons Attribution License, which permits unrestricted use, distribution, and reproduction in any medium, provided the original work is properly cited.

\begin{abstract}
This review examines a variety of adsorbents and discusses mechanisms, modification methods, recovery and regeneration, and commercial applications. A summary of available researches has been composed by a wide range of potentially low-cost modified adsorbents including activated carbon, natural source adsorbents (clay, bentonite, zeolite, etc.), biosorbents (black gram husk, sugar-beet pectin gels, citrus peels, banana and orange peels, carrot residues, cassava waste, algae, algal, marine green macroalgae, etc.), and byproduct adsorbents (sawdust, lignin, rice husk, rice husk ash, coal fly ash, etc.). From the literature survey, different adsorbents were compared in terms of $\mathrm{Zn}^{2+}$ adsorption capacity; also $\mathrm{Zn}^{2+}$ adsorption capacity was compared with other metals adsorption. Thus, some of the highest adsorption capacities reported for $\mathrm{Zn}^{2+}$ are $168 \mathrm{mg} / \mathrm{g}$ powdered waste sludge, $128.8 \mathrm{mg} / \mathrm{g}$ dried marine green macroalgae, $73.2 \mathrm{mg} / \mathrm{g}$ lignin, $55.82 \mathrm{mg} / \mathrm{g}$ cassava waste, and $52.91 \mathrm{mg} / \mathrm{g}$ bentonite. Furthermore, modification of adsorbents can improve adsorption capacity. Regeneration cost is important, but if consumption of virgin adsorbent is reduced, then multiple economic, industrial, and environmental benefits can be gained. Finally, the main drawback of the already published $\mathrm{Zn}^{2+}$ adsorption researches is that their use is still in the laboratory stage mostly without scale-up, pilot studies, or commercialization.
\end{abstract}

\section{Introduction}

Water is a source of energy and life, although millions of people worldwide are suffering from the shortage of clean drinking and fresh water. Rapid pace of population expansion, industrialization, and unplanned urbanization have largely contributed to the severe water pollution and surrounding soils. Discharge of toxic industrial wastes and untreated sanitary, dumping of industrial effluent, and runoff from agricultural fields can be the main sources of freshwater pollution. It is well known that 70 to $80 \%$ of all illnesses in developing countries are related to water contamination, particularly susceptible children and women [1].

Contamination of aqueous environments by heavy metals is a worldwide environmental problem due to their toxic effects and accumulation through the food chain [2].
The major pollutants are heavy metals in ground, marine, industrial, and even treated wastewaters [3]. The presence of heavy metals in drinking water will be hazardous to consumers. $\mathrm{Zn}, \mathrm{Cd}, \mathrm{Hg}, \mathrm{Pb}, \mathrm{Cr}, \mathrm{Cu}$, and so forth can damage liver and nerves and block functional groups of vital enzymes and bones [4]. Metal ions in water can occur naturally from anthropogenic sources and from leaching of ore deposits, which mainly include solid waste disposal and industrial effluents. The levels of heavy metals in water system have substantially increased over time with rapid development of industrial activities [5].

Various regulatory bodies have set the maximum prescribed limits for the discharge of toxic heavy metals in the aquatic systems. However the metal ions are being added to the water stream at a much higher concentration than the prescribed limits by industrial activities, thus leading 
to health hazards and environmental degradation (Table 1) [6]. In Malaysia, the discharge of heavy metals to the water bodies should be stipulated to the limits of standard A and $\mathrm{B}$ according to the Environmental Quality (Sewage and Industrial Effluents) Regulations, Environmental Quality Act 1974 [7].

However, high zinc can cause eminent health problems, such as stomach cramps, vomiting, skin irritations, anemia, and nausea [8]. Various methods are available to remove and isolate these heavy metals from water and wastewater such as ion-exchange, chemical precipitation, membrane filtration, adsorption, and electrochemical treatment technologies [9]. Adsorption is one of the safest, easiest, and most cost-effective methods because it is widely used in effluent treatment processes [10].

On the other hand, solid waste is offered in giant quantities or bound waste merchandise from agricultural operations. Other than that, industrial activities additionally leave behind an enormous quantity of solid waste within the variety of ash. Within the close future, additional increase within the quantity of those waste materials is anticipated to occur, particularly in Malaysia, where rising economies are expected to provide the biggest increase in energy consumption [11].

Therefore, an attempts are made to utilize waste materials as various adsorbents, particularly waste-derived siliceous materials. As a result of their low price, once these materials have been spent, they will be disposed of while regeneration is not expensive. In addition, cost is an important factor for comparing the sorbent materials. However, cost information is rarely reported, and the expense of each sorbent varies depending on local availability and the degree of processing required.

In general, an adsorbent is assumed as "low-cost" if it needs very little processing, is abundant in nature, or could be a byproduct or waste material from another business. As well, enhanced sorption capacity may reward the cost of additional processing. A summary of some of the literature follows reported adsorption capacities that are remarked when possible to give some idea of sorbent effectiveness.

In fact, this review paper provides an outline of a number of the literatures on utilization of low price adsorbents for zinc removal from contaminated water. The authors suggest that the provided review be taken as an example of adsorbents utilized in $\mathrm{Zn}^{2+}$ removal that may be examined beneath a particular set of conditions. Reported adsorption method is noted when there is potential to convey some plan of adsorbent effectiveness. However, the literature usually is not ready to report the full conditions and sufficient area is absent to include conditions here. The readers are requested to seek advice from the original articles for additional data on experimental conditions.

\section{Current Wastewater Treatment Technologies}

Many conventional methods for removal of metal ions from aqueous solutions include ion exchangers, chemical precipitation, chemical oxidation/reduction, electrodialysis, reverse osmosis, and ultrafiltration [12]. However these conventional techniques have their own inherent limitations (Table 2) such as sensitive operating conditions, less efficiency, and production of secondary sludge and further the disposal is a costly affair $[9,13]$. On the other hand, adsorption technology has gained high attention due to its advantages. Applied adsorption science is concerned since early ancient times. Some of the carbon materials such as charcoals were mostly used by few rare specialists [14].

The term adsorption relates to the accumulation of a substance at the interface between two phases such as liquid and solid or gas and solid. The substance which accumulates at the interface is called "adsorbate" and the solid on which adsorption occurs is adsorbent. As well, the adsorption technology has been widely used for the removal of solutes from solutions and gases from air atmosphere. At the solids surface, there are unbalanced forces of attraction which are responsible for adsorption. In cases where the adsorption is due to weak van der Waals forces, it is called physical adsorption. In addition, there may be a chemical bonding between adsorbent and adsorbate molecule and such type of adsorption is referred to as chemical adsorption [14].

In terms of heavy metals removal, adsorption by activated carbon is a popular technology for treating industrial and domestic wastewater [15]. However, the high cost of activated carbon and its loss during the regeneration restricts its application. Since 1990's the adsorption of heavy metal ions by low-cost renewable organic materials has gained momentum [16]. The utilization of moulds, seaweeds, yeasts, and other dead microbial biomass and agricultural waste materials for removal of heavy metals has been explored by Bai and Abraham [17].

Consequently, there is a growing requirement for efficient, novel, and cost-effective techniques for the remediation of metal bearing wastewaters before their discharge into the environment. Over the last two decades, biosorption is one approach which has shown considerable potential for metal removal from aqueous media; that is, the use of raw or natural materials and wastes from agricultural and industrial activities to adsorb metals from aqueous solutions [18].

In addition to that a number of studies have evaluated the application of adsorption for the removal of $\mathrm{Zn}^{2+}$. These include the use of natural materials such as bagasse [19], moss [20], bentonite [21], and mixed mineral [22]; microbial and algal biomass including seaweed, yeast, fungi, and bacteria [23]; industrial and agricultural wastes such as corncobs, peanut hulls, hazelnut shells, corn-starch, waste tea leaves, sea nodule residue, blast furnace slag, sugar beet pulp, lignite, lignin, and powdered waste sludge [3, 16, 24-29]. Despite the relative simplicity and potential cost-effectiveness of adsorption, metal removal using low-cost adsorbents is relatively unproven and needs more development before it may be applied routinely in practice.

\section{Chemically Modified Adsorbents}

Adsorption as one of the physicochemical treatment processes was found to be effective in removing heavy metals 


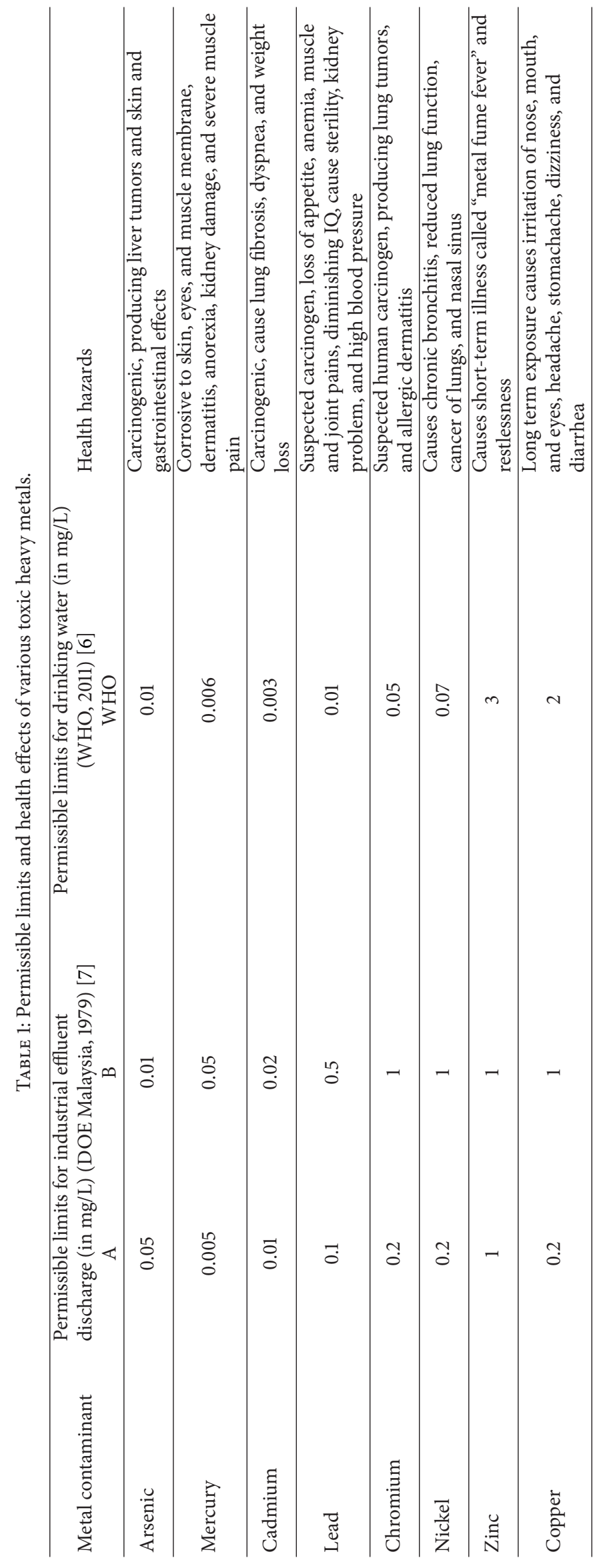


TABLE 2: Comparison among wastewater treatment technologies.

\begin{tabular}{|c|c|c|}
\hline Technique & Advantage & Disadvantage \\
\hline $\begin{array}{l}\text { Chemical } \\
\text { precipitation }\end{array}$ & $\begin{array}{l}\text { (i) Simplicity } \\
\text { (ii) Inexpensive capital cost } \\
\text { (iii) Adapted to treat high heavy metal ions } \\
\text { concentration }\end{array}$ & $\begin{array}{l}\text { (i) Ineffective when metal ion concentration is low } \\
\text { (ii) Not economical } \\
\text { (iii) Produce large amount of sludge }\end{array}$ \\
\hline Ion-exchange & $\begin{array}{l}\text { (i) Widely applied for heavy metal removal } \\
\text { (ii) Ion-exchange resins can be regenerated }\end{array}$ & $\begin{array}{l}\text { (i) Secondary pollution can be caused due to } \\
\text { regeneration by chemical reagents } \\
\text { (ii) Expensive when treating a large amount of } \\
\text { wastewater so cannot be used at large scale }\end{array}$ \\
\hline Membrane filtration & High heavy metal ions removal efficiency & $\begin{array}{l}\text { (i) High cost and complex process. } \\
\text { (ii) Membrane fouling has limited heavy metal removal }\end{array}$ \\
\hline $\begin{array}{l}\text { Coagulation- } \\
\text { flocculation }\end{array}$ & Good sludge settling and dewatering characteristics & $\begin{array}{l}\text { (i) It involves chemical consumption } \\
\text { (ii) Increased sludge volume generation }\end{array}$ \\
\hline Flotation & $\begin{array}{l}\text { (i) High metal selectivity } \\
\text { (ii) High removal efficiency } \\
\text { (iii) High overflow rates } \\
\text { (iv) Low detention periods }\end{array}$ & $\begin{array}{l}\text { (i) High initial capital cost } \\
\text { (ii) High maintenance and operation costs. }\end{array}$ \\
\hline Electrochemical & $\begin{array}{l}\text { (i) Regarded as rapid and well controlled which } \\
\text { requires fewer chemicals } \\
\text { (ii) Provide good reduction yields and produce less } \\
\text { sludge }\end{array}$ & $\begin{array}{l}\text { (i) Involving high initial capital investment } \\
\text { (ii) Expensive electricity supply }\end{array}$ \\
\hline Adsorption & $\begin{array}{l}\text { (i) The high cost of AC limits its use in adsorption } \\
\text { (ii) Many varieties of low-cost adsorbents have been } \\
\text { developed and tested to remove heavy metal ions } \\
\text { (iii) Biosorption is a relatively new process that has } \\
\text { proven very promising for the removal of heavy metal } \\
\text { from wastewater }\end{array}$ & $\begin{array}{l}\text { (i) Removal of heavy metals from low wastewater } \\
\text { concentration } \\
\text { (ii) Adsorption efficiency depends on the type of } \\
\text { adsorbents }\end{array}$ \\
\hline
\end{tabular}

from aqueous solutions. It was showed that an adsorbent can be considered as cheap or low-cost if it is abundant in nature, requires little processing, and is a byproduct of waste material from waste industry. Plant wastes are cheap as they have no or very low economic value [16]. Untreated plant wastes have received a wide attention of adsorption studies such as peanut hull pellets [30], papaya stem [31], rice husk ash, and neem bark [32] saltbush (Atriplex canescens) leaves [33]. Using plant wastes for wastewater treatment has some of the advantages such as simple technique, requiring little processing, adsorption of heavy metal ions, good adsorption capacity, selective, low-cost, and free availability, and easy regeneration.

The chemical modification of plant wastes as adsorbents can solve several problems such as low adsorption capacity, high chemical oxygen demand (COD), biological chemical demand (BOD), and total organic carbon (TOC) due to release of soluble organic compounds contained in the plant materials. The increase of the COD, BOD, and TOC can cause depletion of oxygen content in water and can threaten the aquatic life. Therefore, plant wastes need to be chemically treated or modified before being applied to the decontamination of heavy metals. Also, pretreatment of plant wastes can extract soluble organic compounds and enhance chelating efficiency [34].

Pretreatment methods using different kinds of modifying agents have been used such as base solutions (sodium hydroxide, calcium hydroxide, and sodium carbonate), mineral and organic acid solutions (hydrochloric acid, nitric acid, sulfuric acid, tartaric acid, citric acid, and thioglycolic acid), organic compounds (ethylenediamine, formaldehyde, epichlorohydrin, and methanol), oxidizing agent (hydrogen peroxide), and dye (Reactive Orange 13). For the purpose of removing soluble organic compounds, eliminating coloration of the aqueous solutions and increasing efficiency of metal adsorption have been performed by many researchers [35-38].

3.1. Activated Carbon. Activated carbon has undoubtedly been the most popular and widely used adsorbent in wastewater treatment throughout the world. Charcoal, the forerunner of modern activated carbon, has been recognized as the oldest adsorbent known in wastewater treatment. Activated carbon is produced by a process consisting of raw material dehydration and carbonization followed by activation. The product obtained is known as activated carbon and generally has a very porous structure with a large surface area ranging from 600 to $2000 \mathrm{~m}^{2} / \mathrm{g}$ [14]. Activated carbon has been found to be a versatile adsorbent, which can remove diverse types of pollutants such as metal ions [39].

In spite of better uses of activated carbon, its applications are sometimes restricted due to its higher cost. Therefore, researchers are looking for low-cost adsorbents for water 
pollution control, where cost factors play a major role. As such, for quite some time, efforts have been directed towards developing low-cost alternative adsorbents. Low-cost alternative adsorbents can be prepared from a wide variety of raw materials, which are abundant and cheap, having high organic (carbon) content and low inorganic content and these can be easily activated [40].

Several advantages are shown due to preparation of low-cost adsorbents from waste materials, mainly of environmental nature and economic. A wide variety of lowcost adsorbents have been prepared from different waste materials utilizing agricultural wastes as well as industrial and municipal wastes. Although many studies have been shown so far discussing the importance of low-cost adsorbents in water pollution control, many of them are generally either adsorbate specific (metals, dyes, phenols, etc.) or adsorbent specific $[41,42]$.

3.2. Natural Source Adsorbents. The adsorption ability of clay is caused by a net negative charge on the structure of finegrain silicate minerals. This negative charge is neutralized by the adsorption of positively charged species, giving clay the ability to attract and hold cations such as heavy metals. The large surface area of clays (up to $800 \mathrm{~m}^{2} / \mathrm{g}$ ) also contributes to the high adsorption capacity [43]. There are three basic classes of clays: kaolinite, micas (such as illite), and smectites (e.g., montmorillonite). Of the three species, montmorillonite clays have the smallest crystals, the largest surface area, and the highest cation exchange capacity. Thus montmorillonite clays would be expected to have the highest adsorption capacity.

Gonzalez Pradas et al. [44] examined two types of modifications with natural bentonite, adsorbing $\mathrm{Zn}$ and Cd. Results showed that adsorption capacity decreased by using acid-treatment, while the heat treatment did improve capacity. Whether tailored or in their natural state, due to their abundance, low-cost, and adsorption capabilities, montmorillonite clays are a potential alternative to activated carbon for the adsorption of heavy metals. However, the low permeability of clays could require an artificial support for use in columns.

On the other hand, zeolite can be defined as aluminosilicates with $\mathrm{Si} / \mathrm{Al}$ ratios between 1 and infinity. There are about 40 types of natural zeolite and over 100 synthetic zeolite, they are also considered as selective adsorbents. Zeolite based materials are extremely versatile and their main use includes ion-exchange resins (i.e., water softeners), detergent manufacture, separation process (i.e., molecular sieves), catalytic applications in the petroleum industry, and being an adsorbent for water, carbon dioxide, and hydrogen sulfide. Various zeolite adsorbents have been used for the removal of pollutants [45].

3.3. Biosorbents. Heavy metals biosorption from aqueous solutions is a relatively new process that has been verified as a very promising process in the removal of heavy metal contaminants. The major advantages of biosorption are the use of inexpensive biosorbents and its high effectiveness in reducing the heavy metal ions. Biosorption processes are particularly suitable to treat dilute heavy metal wastewater. Typical biosorbents can be derived from three sources as follows [46]: (1) nonliving biomass such as bark, lignin, shrimp, krill, squid, and crab shell; (2) algal biomass; (3) microbial biomass, for example, bacteria, fungi, and yeast.

On the other hand, biosorbents process has been shown as repetitively used in cycles. The regeneration of adsorbent assents its reuse in further cycles and enables recovery of the adsorbed materials. Adsorbents regeneration can be done by specific methods which involve using chemical reagents. The metal-loaded papaya wood was completely desorbed with $0.1 \mathrm{M} \mathrm{HCl}$. During repeated biosorption-desorption for five cycles, no loss in the efficiency of heavy metals removal from their respective solutions and the metal-loaded biomass was noted. The study points to the potential of a novel use of papaya wood itself, a cause of environmental degradation, and otherwise of no utility for the treatment of wastewaters contaminated with heavy metals [31].

The $\mathrm{Zn}^{+2}$ ions were successively desorbed from Botrytis cinerea (B. cinerea) biomass using $10 \mathrm{mM} \mathrm{HCl}$ solution [23]. Desorption and reusability studies indicated that the biosorbent could be regenerated with up to $98 \%$ recovery and reused five times in biosorption-desorption cycles successively.

3.3.1. Agriculture Waste Adsorbents. There are different forms of inexpensive and non-living plant material such as black gram husk [47], eggshell [48], sugar-beet pectin gels [49] and citrus peels [50] are considered as a potintail adsorbents. Adsorption of divalent heavy metal ions particularly $\mathrm{Cu}^{2+}$, $\mathrm{Zn}^{2+}, \mathrm{Co}^{2+}, \mathrm{Ni}^{2+}$, and $\mathrm{Pb}^{2+}$ onto acid and alkali treated banana and orange peels was performed by Annadurai et al. [51]. The authors reported that residues of banana and orange peels are cellulose-based wastes. Hence, they can be processed and converted to be adsorbents because they have large surface areas, high swelling capacities, and excellent mechanical strengths, are convenient to use, and have great potential to adsorb harmful contaminants such as heavy metals.

In addition, the acid and alkali solutions used for modification of adsorbents were $\mathrm{HNO}_{3}$ and $\mathrm{NaOH}$. Generally, the adsorption capacity decreases in the order of $\mathrm{Pb}^{2+}>$ $\mathrm{Ni}^{2+}>\mathrm{Zn}^{2+}>\mathrm{Cu}^{2+}>\mathrm{Co}^{2+}$ for both adsorbents. Banana peel exhibits higher maximum adsorption capacity for heavy metals compared to orange peel. The reported maximum adsorption capacities were $7.97\left(\mathrm{~Pb}^{2+}\right), 6.88\left(\mathrm{Ni}^{2+}\right), 5.80$ $\left(\mathrm{Zn}^{2+}\right), 4.75\left(\mathrm{Cu}^{2+}\right)$, and $2.55 \mathrm{mg} \mathrm{gl}\left(\mathrm{Co}^{2+}\right)$ using banana peel and were $7.75\left(\mathrm{~Pb}^{2+}\right), 6.01\left(\mathrm{Ni}^{2+}\right), 5.25\left(\mathrm{Zn}^{2+}\right), 3.65\left(\mathrm{Cu}^{2+}\right)$, and $1.82 \mathrm{mg} / \mathrm{g}\left(\mathrm{Co}^{2+}\right)$ using orange peel. Acid treated peels showed better adsorption capacities followed by alkali and water treated peels. Based on regeneration studies, it was reported that the peels could be used for two regenerations for removal and recovery of heavy metal ions.

Heavy metals such as $\mathrm{Cr}^{3+}, \mathrm{Cu}^{2+}$, and $\mathrm{Zn}^{2+}$ were able to be removed from wastewater using $\mathrm{HCl}$ treated carrot residues. Acid treatment was performed in order to remove resins, tannins, colored materials, and reducing sugars. According 
to Nasernejad et al. [52], adsorption of metal ions onto carrot residues was possible due to the cation exchange properties of these residues which was attributed to the presence of carboxylic and phenolic functional groups, which exist in either the cellulosic matrix or in the materials associated with cellulose, such as hemicellulose and lignin. Based on kinetic study, more than $70 \%$ metal ions were removed in the first $10 \mathrm{~min}$ and equilibrium was achieved in $70 \mathrm{~min}$. More metals were adsorbed at higher $\mathrm{pH}$ values of the solutions $(\mathrm{pH} 4$ for $\mathrm{Cr}^{3+}$ and $\mathrm{pH} 5$ for $\mathrm{Cu}^{2+}$ and $\mathrm{Zn}^{2+}$ ). Maximum adsorption capacities were 45.09, 32.74, and $29.61 \mathrm{mg} / \mathrm{g}$ for $\mathrm{Cr}^{3+}, \mathrm{Cu}^{2+}$, and $\mathrm{Zn}^{2+}$, respectively.

Chemically modified adsorbent could also be prepared by thiolation (a process of introducing-SH group) method.

Abia et al. [53] carried out an experiment of determining the optimal concentration of thioglycolic acid $\left(\mathrm{HSCH}_{2} \mathrm{COOH}\right)$ for the removal of $\mathrm{Cd}^{2+}, \mathrm{Cu}^{2+}$, and $\mathrm{Zn}^{2+}$ ions by cassava waste. Cassava waste consists of ligands such as hydroxyl, sulfur, cyano, and amino which could bind heavy metal ions. It was noticed that adsorptivity of the cassava waste was greatly improved as the concentration of modifying agent (thioglycolic acid) was increased from 0.5 to $1.0 \mathrm{M}$ due to the increase in sulfhydryl groups; $-\mathrm{SH}$. Adsorption was reported to take place on the cell wall of the biomass. Optimum adsorptions of all three heavy metals were achieved in less than $30 \mathrm{~min}$. The order of maximum adsorption capacity among the three heavy metal ions after treating cassava waste with $1.0 \mathrm{M}$ thioglycolic acid is as follows: $\mathrm{Zn}^{2+}>$ $\mathrm{Cu}^{2+}>\mathrm{Cd}^{2+}$. The authors however did not conduct a detailed experiment on the kinetic model of adsorption.

Horsfall Jr. and Abia [54] investigate the effect of modifying agent concentration on the adsorption of $\mathrm{Zn}^{2+}$ and $\mathrm{Cd}^{2+}$ ions onto thioglycolic acid for treating cassava waste. Cassava waste treated with $0.5 \mathrm{M}$ and untreated adsorbent showed lowest removal of $\mathrm{Cd}^{2+}$ and $\mathrm{Zn}^{2+}$ ions compared to $1.0 \mathrm{M}$ thioglycolic acid but the time to reach equilibrium remained similar for treated and untreated adsorbent. It was discovered that treated cassava waste sustains a much higher adsorption capacity for $\mathrm{Zn}^{2+}$ and $\mathrm{Cd}^{2+}$ ions compared to untreated sample. The adsorption capacities of treated cassava waste were reported to be $647.48 \mathrm{mg} \mathrm{Cd} / \mathrm{g}$ and $559.74 \mathrm{mg} \mathrm{Zn/g}$, as compared to only $86.68 \mathrm{mg} \mathrm{Cd} / \mathrm{g}$ and $55.82 \mathrm{mg} \mathrm{Zn/g}$ when using untreated cassava waste.

The increase in adsorption capacity of $\mathrm{Zn}$ and $\mathrm{Cd}$ after acid treatment could be related to the formation of microporosity, which leads to enhanced thiol $(-\mathrm{SH})$ groups on the adsorbent surface. The relative release of exchanging hydrogen atoms of the thiol groups with heavy metal ions results in improved level of adsorption. Desorption studies showed that untreated cassava waste showed better recovery of $\mathrm{Zn}^{2+}$ and $\mathrm{Cd}^{2+}$. The authors suggest that the low recovery of heavy metal ions by acid treated cassava waste was due to enhancement in binding sites after acid treatment, which enables the metal ions to bind strongly to the adsorbent surface.

3.3.2. Biomass Adsorbents. Many biomass source adsorbents have been widely investigated as potential biosorbents for heavy metals. Algae, a renewable natural biomass which proliferates ubiquitously and abundantly in the littoral zones of the world, have attracted the attention of many investigators as organisms to be tested and used as new adsorbents to adsorb metal ions. Several advantages in applying algae as biosorbent include the wide availability, low-cost, high metal sorption capacity, and reasonably regular quality [55].

There are a large number of research works on the metal biosorption using algal biomass. Examples of recent reports include the biosorption of $\mathrm{Cu}^{2}, \mathrm{Cd}^{2}, \mathrm{~Pb}^{2}$, and $\mathrm{Zn}^{2}$ using dried marine green macroalga (Caulerpa lentillifera) [56]. The biosorption of $\mathrm{Cu}^{2}$ and $\mathrm{Zn}^{2}$ by dried marine green macroalga (C. linum) was investigated by Ajjabi and Chouba [57]. At the optimum particle size (100 to $315 \mathrm{~mm}$ ), biosorbent dosage $(20 \mathrm{~g} / \mathrm{L})$, and initial solution $\mathrm{pH} 5$, the dried alga produced maximum $\mathrm{Cu}^{2}$ and $\mathrm{Zn}^{2}$ uptake values of 1.46 and $1.97 \mathrm{mmol} / \mathrm{g}$, respectively. Biosorbents were characteristic of broad sources, low-cost, and rapid adsorption. Unfavorably, these researches were still in the theoretic and experimental phase. Moreover, the separation of biosorbents would be difficult after adsorption.

\subsection{Byproduct Adsorbents}

3.4.1. Sawdust. Sawdust is obtained from wood industry as an abundant byproduct which is easily valid in the countryside at inexpensive price. It has been found that it contains several organic compounds (cellulose, lignin, and hemicellulose) with polyphenolic groups that could bind heavy metal ions through different mechanisms. Sciban et al. [58] studied the removal of heavy metal using sawdust. During the adsorption, the leaching of colored organic matters can be removed by pretreatments with formaldehyde in acidic medium, with sodium hydroxide solution after formaldehyde treatment, or with sodium hydroxide only.

In another experiment on the use of sawdust in the removal of $\mathrm{Cu}^{2+}$ and $\mathrm{Zn}^{2+}$ ions was reported by Sciban et al. [59]. Two types of sawdust, fir and poplar woods, were treated with $\mathrm{NaOH}$ (fiber swelling agent) and $\mathrm{Na}_{2} \mathrm{CO}_{3}$ solutions and the adsorption capacities were compared with the untreated sawdust. Both unmodified sawdust types of woods showed higher uptakes of $\mathrm{Cu}^{2+}$ ions than $\mathrm{Zn}^{2+}$ ions. Both types of sawdust record equivalent amounts of adsorption capacities for $\mathrm{Zn}^{2+}$ and $\mathrm{Cu}^{2+}$ ions, although it showed that these two adsorbents have different chemical compositions and anatomical structures. Increasing in adsorption capacity was observed after treating with $\mathrm{NaOH}$ for both heavy metal ions, especially for $\mathrm{Zn}^{2+}$ ions (2.5 times for $\mathrm{Cu}^{2+}$ and 15 times for $\mathrm{Zn}^{2+}$ ). The adsorption capacities showed by Langmuir model were $15.83 \mathrm{mg} / \mathrm{g}$ (poplar sawdust) and $13.41 \mathrm{mg} / \mathrm{g}$ for $\mathrm{Zn}^{2+}$ (fir sawdust) and $6.92 \mathrm{mg} / \mathrm{g}$ (poplar sawdust) and $12.70 \mathrm{mg} / \mathrm{g}$ (fir sawdust) for $\mathrm{Cu}^{2+}$, respectively.

3.4.2. Lignin. Srivastava et al. [60] studied adsorption of $\mathrm{Pb}$ and zinc $(\mathrm{Zn})$ onto lignin. The lignin was extracted from black liquor, a waste product of the paper industry. Waste black liquor can be purchased for $\$ 1.00 /$ ton, and the lignin can be processed for approximately $\$ 60 /$ ton, as compared 
to activated carbon at $\$ 100 /$ ton. The adsorption capacity for lignin at $30^{\circ} \mathrm{C}$ was found to be $1587 \mathrm{mg} / \mathrm{g}$ for $\mathrm{Pb}$ and $73 \mathrm{mg} / \mathrm{g}$ for $\mathrm{Zn}$, which increased to 1865 and $95 \mathrm{mg} / \mathrm{g}$, respectively, at $40^{\circ} \mathrm{C}$. The high adsorption capacity of lignin is in part due to polyhydric phenols and other functional groups on the surface. Ion-exchange may also play a role in the adsorption of metals by lignin.

3.4.3. Rice Husk and Rice Husk Ash. Rice husk has good chemical stability, is insoluble in water, possesses a granular structure, and has high mechanical strength, which shows it is a good adsorbent material for removal of heavy metals from wastewater. Rice husk has been extensively reviewed by Chuah et al. [61] for heavy metals removal. Many heavy metal ions studied include $\mathrm{Zn}, \mathrm{Pb}, \mathrm{Cd}, \mathrm{Cu}, \mathrm{Co}, \mathrm{Au}$, and $\mathrm{Ni}$. Rice husk in the form of either untreated or modified by different modification methods has been widely used to treat heavy metals. Sodium carbonate and hydrochloric acid [36], epichlorohydrin and sodium hydroxide [32], and tartaric acid are common chemical treatment methods of rice husk [62].

Rice husks pretreatment can remove hemicellulose and lignin, reduce cellulose crystallinity, and increase the surface area or porosity. In general, unmodified rice husk showed lower adsorption capacities on heavy metal ions than on treated or chemically modified rice husk. It was reported by Kumar and Bandyopadhyay [36] that rice husk treated with sodium carbonate, sodium hydroxide, and epichlorohydrin enhanced the adsorption capacity of heavy metal. Also it was reported that, for instance, interference with adsorption property might happen due to using the base treatment $\mathrm{NaOH}$ to remove base soluble materials on the rice husk surface.

Bhattacharya et al. [32] has studied rice husk ash with pretreatment for $\mathrm{Zn}^{+2}$ removals. It was found that $96.8 \%$ of $\mathrm{Zn}^{+2}$ removals were obtained at a $\mathrm{pH}$ value of 5 . The Langmuir and Freundlich adsorption isotherm models were used to represent the experimental data. Both of the models were fitted well. The adsorption capacity was obtained at $14.30 \mathrm{mg} / \mathrm{g}$ at optimum $\mathrm{pH} 5.0$.

In another study by Montanher et al. [63], rice bran was evaluated for its potential use as an adsorbent for $\mathrm{Cd}^{2+}, \mathrm{Cu}^{2+}$, $\mathrm{Pb}^{2+}$, and $\mathrm{Zn}^{2+}$. Rice bran adsorbent is able to successfully adsorb the metal ions from aqueous solutions. Maximum efficiency of $72 \%$ for $\mathrm{Zn}^{2+}$ removal was observed in chloride medium and $\mathrm{NaCl} 0.1 \mathrm{~mol} / \mathrm{L}$ has been used throughout the work. The experimental data were well fitted to the Freundlich equation, with good correlation coefficients.

Two types of adsorbents made from rice husk by two different routes of preparation were examined by Daifullah et al. [64]. The efficiency of both sorbents in the removal of the complex matrix containing six heavy metals (Fe, Mn, Zn, $\mathrm{Cu}, \mathrm{Cd}$, and $\mathrm{Pb}$ ) was $\approx 100 \%$. These heavy metals are found in the drain containing the agriculture and sewage wastewater.

3.4.4. Coal Fly Ash. Since the industrial revolution which started in the 1920s a wide scale coal burning for power generation began. Although there were many millions of tons of related byproducts and ash that have been generated, it was estimated that the current annual production of coal ash worldwide is around 600 million tons, with fly ash forming about 500 million tons at $75-80 \%$ of the total ash produced. Thus, the amount of fly ash as a coal waste released by thermal power plants and factories has been increasing throughout the world. Likewise, a serious environmental problem has become evident due to the disposal of the large quantities of fly ash. Nowadays utilization of ash on worldwide basis varied widely from a maximum of $57 \%$ to a minimum of $3 \%$, so the world average amounts only to $16 \%$ of the total ash present. In fact, consumers companies are facing many utilizing problems due to the significant cost of the mostly amount of ash has disposed of in landfills or/and lagoons [65].

Gangoli et al. [66] reported the utilization of fly ash for the removal of heavy metals from industrial wastewaters. As a low-cost adsorbent, fly ash has been widely utilized for the removal of heavy metal. Among these metal ions $\mathrm{Zn}, \mathrm{Ni}$, $\mathrm{Cu}, \mathrm{Pb}, \mathrm{As}, \mathrm{Cr}, \mathrm{Cd}$, and $\mathrm{Hg}$ are the most often investigated metals. As early as 1975, the use of fly ash for removal of heavy metals was reported. Bayat [67] investigated the removal of $\mathrm{Zn}^{2+}$ and $\mathrm{Cd}^{2+}$ and $\mathrm{Zn}^{2+}, \mathrm{Ni}^{2+}$, and $\mathrm{Cu}^{2+}$ [68], using lignite-based fly ash and activated carbon and discovered that fly ash was effective as activated carbon. The percent adsorption of $\mathrm{Zn}^{2+}$ and $\mathrm{Cd}^{2+}$ increased with an increase in concentration of $\mathrm{Zn}^{2+}$ and $\mathrm{Cd}^{2+}$, dosage of fly ash, and temperature; maximum adsorption occurred in the $\mathrm{pH}$ range of 7.0-7.5. The effectiveness of fly ash as an adsorbent modified with increased calcium content $(\mathrm{CaO})$.

Fly ash and fly ash/lime mixture were reported for removal of $\mathrm{Zn}, \mathrm{Ni}, \mathrm{Cu}, \mathrm{Cd}$, and $\mathrm{Pb}[69,70]$. The extent of removal was achieved in the order of $\mathrm{Pb}^{2+}>\mathrm{Cu}^{2+}>\mathrm{Ni}^{2+}>$ $\mathrm{Zn}^{2+}>\mathrm{Cd}^{2+}$. Due to formation of calcium silicate hydrates $(\mathrm{CSH})$, metals removal efficiency may increase and desorption rate may decrease. Two fluidized-bed-sourced fly ashes were investigated by Rio et al. [71] with different chemical compositions; sulfocalcic fly ash and silicoaluminous fly ash were reported to remove $\mathrm{Zn}^{2+}, \mathrm{Cu}^{2+}, \mathrm{Cr}(\mathrm{III}), \mathrm{Ni}^{2+}, \mathrm{Pb}^{2+}$, and $\mathrm{Cr}(\mathrm{VI})$ from aqueous solutions. The percentage of ions removal was lower when they were treated with sulfocalcic fly ash than when treated with silicoaluminous fly ash, except in the case of the ion $\mathrm{Ni}^{2+}$. Mercury is bound to the ash surface due to several chemical reactions between mercury and various oxides (silicon, aluminum, and calcium silicate), on the surface of the ash.

A series of investigations was conducted on the adsorption of heavy metals, using bagasse fly ash adsorbent. Bagasse fly ash from sugar industries was used for the removal of zinc and copper from aqueous solutions [72, 73]. Zinc and copper are adsorbed by the developed adsorbent up to 90 to $95 \%$ in column and batch experiments. The removal of $\mathrm{Zn}$ is $100 \%$ at low concentrations, whereas removal is 60 to $65 \%$ at higher concentrations. The removal decreases with increased temperature, suggesting that the process is exothermic in nature.

After the adsorption process, fly ash can be regenerated using certain reagents. Batabyal et al. [74] reported that 
saturated fly ash can be regenerated using $2 \%$ of aqueous $\mathrm{H}_{2} \mathrm{O}_{2}$ solution. The regenerated fly ash was dried, cooled, and used for further adsorption. The adsorption rate and equilibrium time were the same as the fresh fly ash particles.

\section{Adsorbents Application in Industrial Scale}

Innovative processes for treating real industrial wastewater containing heavy metals often involve technologies for reduction of toxicity in order to meet effluents and technologybased treatment standards. Recently, there are a large number of adsorption studies on zinc removal, mostly from synthetic wastewater in a lab scale [75]. However, the potential of zinc adsorption remains great in wide range of industrial applications. Subsequently, selection and identification of an appropriate commercial adsorbent is one of the key issues for industrial applications [76]. A number of materials have been extensively investigated as adsorbents in water pollution control. Some of the commercial ones include silica gel, activated alumina, zeolites, and activated carbon [14].

Activated carbon is the most commercially used adsorbent material. The world demand for virgin activated carbon is forecasted to expand 5.2 percent per year through 2012 to 1.15 million metric tons. The consumption of activated carbons for industrial use has now become an indicator of development and environmental management efficiency. The per capita consumption of activated carbons per year is $0.5 \mathrm{~kg}$ in Japan, $0.4 \mathrm{~kg}$ in the United States, $0.2 \mathrm{~kg}$ in Europe, and $0.03 \mathrm{~kg}$ in the rest of the world [77]. In addition, natural zeolite was applied in full scale treatment plant for heavy metal removal from industrial effluents. The adsorbent was dosed in two separate tanks, in order to reach maximum removal efficiency [78].

Cost factor of commercial application of adsorption is another key issue and should not be ignored. Low production cost with higher removal efficiency of adsorbents would make the process economical and efficient. However, limited attempts for detailed economic and market analyses of scaleup (from lab to industry) are available [76]. As adsorption is applied in industry, modification of adsorbent is necessary for solid/liquid separation. Packed columns offer a potential configuration for industrial implementation, especially for the removal of $\mathrm{Zn}$. Modified adsorbent beads can then be packed in sorption column, which is perhaps the most effective device for continuous operations [79].

In contrast, reactive filtration columns using natural adsorbent (Pine Bark) materials constitute a promising and suitable process for zinc remediation as a suitable alternative to the conventional sand porous media, due to the their additional adsorptive. Ultimately, up to $95 \%$ of Zinc was removed during the first month of the operation [80]. At real-scale, heavy metal removal efficiency of $95 \%$ was also achieved in reactive filters using iron oxide [81].

Heavy metal removal from pharmaceutical industry and hospitals was conducted in a pilot scale using granular activated carbon. The pilot plant system consisted of two adsorbent columns in series. The GAC system removed $99.8 \%$ of the mercury from the wastewater. It was also effective in removing $90 \%$ of copper. The treatment system was also effective for removal of turbidity (99\%), color (99\%), and phenols (96\%) from the wastewater [82]. Ramísio and Vieira [83] have installed a dual-media adsorptive filter using kaolinite and sand adsorbents, and it consisted of two reservoirs and three columns. Adsorption of metals to filter materials has been studied using different heavy metal removals. Outputs data show that $\mathrm{Zn}$ is the most mobile metal with retention efficiency values decreasing to less than $50 \%$.

Furthermore, a subsurface permeable reactive barrier (PRB) was used to remediate acid mine drainage in a shallow alluvial groundwater containing elevated concentrations of $\mathrm{Zn}, \mathrm{Pb}, \mathrm{Cd}, \mathrm{Cu}, \mathrm{SO}_{4}$, and $\mathrm{NO}_{3}$. The $\mathrm{PRB}$ was filled with 90 tons of reactive Apatite II (US Patent number 6,217,775), a biogenically precipitated apatite material that is derived from fish bones. The emplaced PRB has been operating successfully and has reduced the concentrations of $\mathrm{Zn}$ from 64.5 to $0.086 \mathrm{mg} / \mathrm{L}$ [84].

As compared to many commercial adsorbents, biosorbents have presented commercial potential and application feasibility in wide range of industrial applications. A considerable amount of research on biosorbent materials has developed a solid basis of knowledge and indicated their enormous potential [85]. The company Resource Management \& Recovery offers commercial portable regimes for heavy metal removal from aqueous solutions. It consists of two columns each containing $7 \mathrm{~L}$ of the biosorbent. The company declares effluent treatment efficiency of $0.5 \mathrm{~L} / \mathrm{min}$ and that it is possible to construct larger systems with 100 times higher treatment efficiency by implementing larger columns or adding additional columns to the system [86].

Mayes et al. [87] investigated the biosorption of $\mathrm{Zn}^{2+}$ from metal mine water using pelletised and recovered hydrous ferric oxide adsorbent. The treatment system consisted of baffled treatment tank filled with adsorbent media. At a low mean residence time of 49 mins, a mean treatment efficiency of $32 \%$ was achieved. United States Bureau of Mines (Golden, Colorado) produced the granular biofix, which has been tested extensively for the treatment of acid mine waste [88]. The results showed that the $\mathrm{Zn}$ binding to the biosorbent BIO-FIX is about 4-fold higher than the ion-exchange resins. The metal affinity was as follows: $\mathrm{Al}^{3+}>\mathrm{Cd}^{2+}>\mathrm{Zn}^{2+}>\mathrm{Mn}^{2+}$ and a much lower affinity for $\mathrm{Mg}^{2+}$ and $\mathrm{Ca}^{2+}$.

The future aspects are clear. The main future target of market is to move the adsorption process to an industrial scale. It is relatively less difficult to demonstrate it in a laboratory; it is a little more challenging to demonstrate it at a pilot scale, but to really scale it up to a large scale would call for a significant financial and technological effort. This mismatch between scientific progress in adsorption research and stagnation in industrial technology innovation needs to be corrected through translational research and technology transfer with a push for commercialization of research.

\section{Adsorbents Regenerations and Limitations}

The adsorption process shows flexibility in design and operation and in many cases will produce high-quality treated 
TABLE 3: Adsorption capacities of different adsorbents for the removal of $\mathrm{Zn}^{2+}$ from water.

\begin{tabular}{|c|c|c|c|c|}
\hline Adsorbent & $\mathrm{Zn}^{+2} \mathrm{mg} / \mathrm{L}$ & Modifying agent(s) & $Q_{\max } \mathrm{mg} / \mathrm{g}$ & Source \\
\hline Bagasse & 200 & Sulfuric acid & 31.11 & {$[19]$} \\
\hline Moss & 100 & Distilled water & 14.7 & {$[20]$} \\
\hline Bentonite & 300 & - & 52.91 & {$[95]$} \\
\hline Botrytis cinerea & 100 & $\mathrm{NaOH}$ & 12.98 & {$[23]$} \\
\hline Sea nodule residue & 200 & Hydrochloric acid & 32.46 & {$[24]$} \\
\hline Powdered waste sludge & 200 & $\mathrm{H}_{2} \mathrm{O}_{2}$ & 168 & {$[25]$} \\
\hline Waste activated sludge & 16 & - & 36.9 & {$[26]$} \\
\hline Sugar beet pulp & 160 & Deionized water & 17.78 & [27] \\
\hline Papaya wood & 10 & Deionized water & 13.64 & {$[31]$} \\
\hline Clarified sludge & 25 & Distilled water & 15.53 & \multirow{4}{*}[32]{} \\
\hline Rice husk ash & & Distilled water & 14.30 & \\
\hline Neem bark & & Distilled water & 13.29 & \\
\hline Activated alumina & & - & 13.69 & \\
\hline Saltbush leaves & - & $\mathrm{HCl}$ & 32.7 & [33] \\
\hline Natural zeolite & 120 & - & 2.21 & {$[45]$} \\
\hline Black gram husk & 10 & Distilled water & 33.81 & [47] \\
\hline Carrot residues & 500 & $\mathrm{HCl}$ & 29.61 & {$[52]$} \\
\hline Cassava waste & - & $\begin{array}{c}\text { Untreated } \\
\text { Thioglycollic acid }+\mathrm{HNO}_{3}\end{array}$ & $\begin{array}{c}55.82 \\
559.74\end{array}$ & {$[54]$} \\
\hline Caulerpa lentillifera & 10 & Tab water & 2.66 & {$[56]$} \\
\hline Dried marine green macroalga & 260 & $\mathrm{CaCl}_{2}$ & 128.8 & {$[57]$} \\
\hline Sawdust-oak & - & Unmodified & 7.1 & \multirow{12}{*}[58]{} \\
\hline Sawdust-oak & - & Formaldehyde & 6.1 & \\
\hline Sawdust-oak & - & Formaldehyde $+\mathrm{NaOH}$ & 9.3 & \\
\hline Sawdust-oak & - & $\mathrm{NaOH}$ & 8.3 & \\
\hline Sawdust-black locust & - & Unmodified & 5.2 & \\
\hline Sawdust-black locust & - & Formaldehyde & 5.3 & \\
\hline Sawdust-black locust & - & Formaldehyde $+\mathrm{NaOH}$ & 9 & \\
\hline Sawdust-black locust & - & $\mathrm{NaOH}$ & 6.7 & \\
\hline Sawdust-poplar & 196 & Unmodified & 1 & \\
\hline Sawdust-fir & 196 & Unmodified & 1 & \\
\hline Sawdust-poplar & 130 & $\mathrm{NaOH}$ & 15.8 & \\
\hline Sawdust-fir & 40 & $\mathrm{NaOH}$ & 13.4 & \\
\hline Lignin & 6.5 & $\mathrm{HCl}+$ ether + benzene & 73.2 & {$[60]$} \\
\hline Bagasse fly ash & 50 & Hydrogen peroxide & 2.34 & {$[72]$} \\
\hline \multirow{3}{*}{ Bagasse } & 850 & Activated carbon $\left(10^{\circ} \mathrm{C}\right)$ & 24.06 & \multirow{3}{*}{ [19] } \\
\hline & 800 & Activated carbon $\left(25^{\circ} \mathrm{C}\right)$ & 31.11 & \\
\hline & 775 & Activated carbon $\left(40^{\circ} \mathrm{C}\right)$ & 54 & \\
\hline Coal fly ash & & Unmodified $\left(30-60^{\circ} \mathrm{C}\right)$ & $6.5-13.3$ & \multirow{3}{*}[96]{} \\
\hline Fe impregnated fly ash & & $\mathrm{Fe}(\mathrm{Cl})_{3}\left(30-60^{\circ} \mathrm{C}\right)$ & $7.5-15.5$ & \\
\hline $\mathrm{Al}$ impregnated fly ash & & $\mathrm{Al}\left(\mathrm{NO}_{3}\right)_{3}\left(30-60^{\circ} \mathrm{C}\right)$ & $7.0-15.4$ & \\
\hline Rice husk ash + coal fly ash + palm oil fuel ash & 15 & Sol gel method & 16.95 & [97] \\
\hline
\end{tabular}

effluent. Choosy adsorption utilizing biological materials, mineral oxides, activated carbon, and polymer resins have generated much excitement among researchers, scientists, and environmental engineers [8]. After the adsorbents are exhausted, they are either to be disposed of or regenerated for use. This depends upon the demand, economics involved, and the kind of pollutant that was adsorbed.
Although adsorption is sometimes correctable, adsorbents can be regenerated by suitable desorption process. Furthermore, very few regeneration studies of adsorbents loaded with zinc are detailed in the literature [89-91]. Once zinc is recovered in the concentrated solution, the issue of how to dispose of this concentrated zinc product must be addressed. The metal ion attached on the adsorbent creates 
disposal problem as it is hazardous matter. This problem may be controlled to some scope by using elution methods. The elution of the heavy metals provides recovery of the metal ions in the concentrated form and the regenerated adsorbents. The concentrated metal solution may be convenient for recovery of the metal. The regenerated adsorbent may be recycled for reuse and ultimately the adsorbents must be incinerated [92].

This is a difficult task; the limitation is low-cost and properties of the suggested adsorbents discourage significant investment in regeneration. Adsorbent regeneration may account for a large portion of operating costs. Also, adsorbent regeneration may cause secondary pollution. Under such circumstances, a feasible solution is proposed to dispose the adsorbent and its contaminations into a sanitary landfill. In many cases, spent adsorbents are to be treated as hazardous waste and need to be incinerated (which in many countries causes a set of environmental and societal problems) [93].

\section{Comparison of $\mathrm{Zn}^{2+}$ Adsorption Capacity by Different Adsorbents}

Adsorption capacity is the key-point of each adsorbent material. The adsorption capacity $(\mathrm{mg} / \mathrm{g})$ is the amount of the molecule adsorbed (the adsorbate) per unit mass of the adsorbent at a given gas-phase concentration under equilibrium conditions. It corresponds to one point on the adsorption isotherm [94]. The maximum adsorption capacities of different adsorbents for the removal of $\mathrm{Zn}^{2+}$ have been compared with extensive reports in the literature and the values of adsorption capacities have been shown in Table 3. Nevertheless, the maximum adsorption capacity $\left(Q_{\max } \mathrm{mg} / \mathrm{g}\right)$ is usually calculated from an adsorption isotherm equation, based on equilibrium data. Also, it was noticed that modification of the adsorbents can also improve $\mathrm{Zn}^{2+}$ adsorption capacity. The experimental data of the present enquiries are comparable with the reported values.

\section{Conclusion}

During this review article, an assay has been made to specialize in the recent developments associated with $\mathrm{Zn}^{2+}$ removal by low-cost adsorbents utilizing agriculture and agroindustrial wastes. It absolutely was demonstrated from the literature that utilization of waste materials as lowcost adsorbents for removing $\mathrm{Zn}^{2+}$ presents many enticing features particularly their contribution within the reduction of costs for waste disposal, hence promoting environmental protection. Also, adsorbents may be regenerated and recycled for reuse but may account a large portion of operating costs. Due to their low-cost, after these materials have been expended, they can be disposed of without expensive regeneration. The literature indicated that only limited references are available on industrial applications and only a few studies were reported. Furthermore, more studies should be carried out for $\mathrm{Zn}^{2+}$ removal in large scale.

\section{Conflict of Interests}

The authors declare that there is no conflict of interests regarding the publication of this paper.

\section{References}

[1] WHO/UNICEF, Global Water Supply and Sanitation Assessment Report 2000, WHO, Geneva, Switzerland, 2000.

[2] T. Bohli, A. Ouederni, N. Fiol, and I. Villaescusa, "Single and binary adsorption of some heavy metal ions from aqueous solutions by activated carbon derived from olive stones," Desalination and Water Treatment, 2013.

[3] E. Valdman, L. Erijman, F. L. P. Pessoa, and S. G. F. Leite, "Continuous biosorption of $\mathrm{Cu}$ and $\mathrm{Zn}$ by immobilized waste biomass Sargassum sp," Process Biochemistry, vol. 36, no. 8-9, pp. 869-873, 2001.

[4] N. S. Awwad, A. A. El-Zahhar, A. M. Fouda, and H. A. Ibrahium, "Removal of heavy metal ions from ground and surface water samples using carbons derived from date pits," Journal of Environmental Chemical Engineering, vol. 1, no. 3, pp. 416-423, 2013.

[5] J. Nouri, A. H. Mahvi, A. A. Babaei, G. R. Jahed, and E. Ahmadpour, "Investigation of heavy metals in groundwater," Pakistan Journal of Biological Sciences, vol. 9, no. 3, pp. 377-384, 2006.

[6] WHO, World Health Organization, Guidelines For DrinkingWater Quality, Geneva, Switzerland, 4th edition, 2011.

[7] DOE Malaysia, "Environmental Quality Act 1974, Environmental Quality (Sewage and Industrial Effluents): Selected parameter limits of effluent of Standards A and B," 1979.

[8] H. M. Zwain, Comprehensive Study on Wastewater Treatment Using Low Cost Adsorbent, LAP Lambert Academic Publishing, Saarbrücken, Germany, 2012.

[9] F. Fu and Q. Wang, "Removal of heavy metal ions from wastewaters: a review," Journal of Environmental Management, vol. 92, no. 3, pp. 407-418, 2011.

[10] D. Balkose and H. Baltacioglu, "Adsorption of heavy metal cations from aqueous solutions by wool fibers," Journal of Chemical Technology and Biotechnology, vol. 54, no. 4, pp. 393397, 1992.

[11] I. Dahlan and H. M. Zwain, "A study on the removal characteristic of zinc ion $\left(\mathrm{Zn}^{2+}\right)$ from synthetic wastewater using a novel waste-derived siliceous sorbent," Caspian Journal of Applied Sciences Research, vol. 2, no. 6, pp. 10-17, 2013.

[12] J. L. Gardea-Torresdey, J. H. Gonzalez, K. J. Tiemann, O. Rodriguez, and G. Gamez, "Phytofiltration of hazardous cadmium, chromium, lead and zinc ions by biomass of Medicago sativa (Alfalfa)," Journal of Hazardous Materials, vol. 57, no. 1-3, pp. 29-39, 1998.

[13] S. S. Ahluwalia and D. Goyal, "Removal of heavy metals by waste tea leaves from aqueous solution," Engineering in Life Sciences, vol. 5, no. 2, pp. 158-162, 2005.

[14] A. Bhatnagar and M. Sillanpää, "Utilization of agro-industrial and municipal waste materials as potential adsorbents for water treatment-a review," Chemical Engineering Journal, vol. 157, no. 2-3, pp. 277-296, 2010.

[15] M. Hosea, B. Greene, R. Mcpherson, M. Henzl, M. Dale Alexander, and D. W. Darnall, "Accumulation of elemental gold on the alga Chlorella vulgaris," Inorganica Chimica Acta, vol. 123, no. 3, pp. 161-165, 1986. 
[16] S. E. Bailey, T. J. Olin, R. M. Bricka, and D. D. Adrian, "A review of potentially low-cost sorbents for heavy metals," Water Research, vol. 33, no. 11, pp. 2469-2479, 1999.

[17] R. S. Bai and T. E. Abraham, "Studies on chromium(VI) adsorption-desorption using immobilized fungal biomass," Bioresource Technology, vol. 87, no. 1, pp. 17-26, 2003.

[18] B. Volesky, Sorption and Biosorption, BV Sorbex, St. Lambert, Quebec, Canada, 2003.

[19] D. Mohan and K. P. Singh, "Single- and multi-component adsorption of cadmium and zinc using activated carbon derived from bagasse-an agricultural waste," Water Research, vol. 36, no. 9, pp. 2304-2318, 2002.

[20] R. J. E. Martins, R. Pardo, and R. A. R. Boaventura, "Cadmium(II) and zinc(II) adsorption by the aquatic moss Fontinalis antipyretica: effect of temperature, $\mathrm{pH}$ and water hardness," Water Research, vol. 38, no. 3, pp. 693-699, 2004.

[21] K. Bellir, M. B. Lehocine, and A.-H. Meniai, "Zinc removal from aqueous solutions by adsorption onto bentonite," Desalination and Water Treatment, vol. 51, no. 25-27, pp. 5035-5048, 2013.

[22] D. E. Egirani, A. R. Baker, and J. E. Andrews, "Copper and zinc removal from aqueous solution by mixed mineral systems: II. The role of solution composition and aging," Journal of Colloid and Interface Science, vol. 291, no. 2, pp. 326-333, 2005.

[23] S. Tunali and T. Akar, " $\mathrm{Zn}$ (II) biosorption properties of Botrytis cinerea biomass," Journal of Hazardous Materials, vol. 131, no. 13, pp. 137-145, 2006.

[24] A. Agrawal, K. K. Sahu, and B. D. Pandey, "Removal of zinc from aqueous solutions using sea nodule residue," Colloids and Surfaces A: Physicochemical and Engineering Aspects, vol. 237, no. 1-3, pp. 133-140, 2004.

[25] F. Kargi and S. Cikla, "Zinc (II) ion recovery by biosorption onto powdered waste sludge (PWS): effects of operating conditions," Journal of Chemical Technology and Biotechnology, vol. 81, no. 10, pp. 1661-1668, 2006.

[26] L. Norton, K. Baskaran, and T. McKenzie, "Biosorption of zinc from aqueous solutions using biosolids," Advances in Environmental Research, vol. 8, no. 3-4, pp. 629-635, 2004.

[27] Z. Reddad, C. Gerente, Y. Andres, and P. Le Cloirec, "Adsorption of several metal ions onto a low-cost biosorbent: kinetic and equilibrium studies," Environmental Science and Technology, vol. 36, no. 9, pp. 2067-2073, 2002.

[28] R. Tabaraki, S. Ahmady-Asbchin, and O. Abdi, "Biosorption of $\mathrm{Zn}$ (II) from aqueous solutions by Acinetobacter sp. isolated from petroleum spilled soil," Journal of Environmental Chemical Engineering, vol. 1, no. 3, pp. 604-608, 2013.

[29] Y.-N. Chen, D.-C. Zhang, M. Chen, and Y.-C. Ding, "Biosorption properties of cadmium (II) and Zinc(II) from aqueous solution by tea fungus," Desalination and Water Treatment, vol. 8, no. 1-3, pp. 118-123, 2009.

[30] P. D. Johnson, M. A. Watson, J. Brown, and I. A. Jefcoat, "Peanut hull pellets as a single use sorbent for the capture of $\mathrm{Cu}(\mathrm{II})$ from wastewater," Waste Management, vol. 22, no. 5, pp. 471480, 2002.

[31] A. Saeed, M. W. Akhter, and M. Iqbal, "Removal and recovery of heavy metals from aqueous solution using papaya wood as a new biosorbent," Separation and Purification Technology, vol. 45, no. 1, pp. 25-31, 2005.

[32] A. K. Bhattacharya, S. N. Mandal, and S. K. Das, "Adsorption of $\mathrm{Zn}$ (II) from aqueous solution by using different adsorbents," Chemical Engineering Journal, vol. 123, no. 1-2, pp. 43-51, 2006.
[33] M. F. Sawalha, J. R. Peralta-Videa, J. Romero-González, M. Duarte-Gardea, and J. L. Gardea-Torresdey, "Thermodynamic and isotherm studies of the biosorption of $\mathrm{Cu}(\mathrm{II}), \mathrm{Pb}(\mathrm{II})$, and $\mathrm{Zn}$ (II) by leaves of saltbush (Atriplex canescens)," Journal of Chemical Thermodynamics, vol. 39, no. 3, pp. 488-492, 2007.

[34] I. Gaballah, D. Goy, E. Allain, G. Kilbertus, and J. Thaurónt, "Recovery of copper through decontamination of synthetic solutions using modified barks," Metallurgical and Materials Transactions B: Process Metallurgy and Materials Processing Science, vol. 28, no. 1, pp. 13-23, 1997.

[35] V. K. Gupta, C. K. Jain, I. Ali, M. Sharma, and V. K. Saini, "Removal of cadmium and nickel from wastewater using bagasse fly ash-a sugar industry waste," Water Research, vol. 37, no. 16, pp. 4038-4044, 2003.

[36] U. Kumar and M. Bandyopadhyay, "Sorption of cadmium from aqueous solution using pretreated rice husk," Bioresource Technology, vol. 97, no. 1, pp. 104-109, 2006.

[37] B. R. Reddy, N. Mirghaffari, and I. Gaballah, "Removal and recycling of copper from aqueous solutions using treated Indian barks," Resources, Conservation and Recycling, vol. 21, no. 4, pp. 227-245, 1997.

[38] V. C. Taty-Costodes, H. Fauduet, C. Porte, and A. Delacroix, "Removal of $\mathrm{Cd}(\mathrm{II})$ and $\mathrm{Pb}(\mathrm{II})$ ions, from aqueous solutions, by adsorption onto sawdust of Pinus sylvestris," Journal of Hazardous Materials, vol. 105, no. 1-3, pp. 121-142, 2003.

[39] C. Gabaldón, P. Marzal, J. Ferrer, and A. Seco, "Single and competitive adsorption of $\mathrm{Cd}$ and $\mathrm{Zn}$ onto a granular activated carbon," Water Research, vol. 30, no. 12, pp. 3050-3060, 1996.

[40] C. Moreno-Castilla and J. Rivera-Utrilla, "Carbon materials as adsorbents for the removal of pollutants from the aqueous phase," MRS Bulletin, vol. 26, no. 11, pp. 890-894, 2001.

[41] S. Babel and T. A. Kurniawan, "Low-cost adsorbents for heavy metals uptake from contaminated water: a review," Journal of Hazardous Materials, vol. 97, no. 1-3, pp. 219-243, 2003.

[42] S. J. T. Pollard, G. D. Fowler, C. J. Sollars, and R. Perry, "Lowcost adsorbents for waste and wastewater treatment: a review," Science of the Total Environment, vol. 116, no. 1-2, pp. 31-52, 1992.

[43] F. Cadena, R. Rizvi, and R. W. Peters, "Feasibility studies for the removal of heavy metals from solution using tailored bentonite," in Proceedings of the 22nd Mid-Atlantic Industrial Waste Conference, pp. 77-94, July 1990.

[44] E. Gonzalez Pradas, M. Villafranca Sanchez, F. Canton Cruz, M. Socias Viciana, and M. Fernandez Perez, "Adsorption of cadmium and zinc from aqueous solution on natural and activated bentonite," Journal of Chemical Technology and Biotechnology, vol. 59, no. 3, pp. 289-295, 1994.

[45] T. Motsi, N. A. Rowson, and M. J. H. Simmons, "Adsorption of heavy metals from acid mine drainage by natural zeolite," International Journal of Mineral Processing, vol. 92, no. 1-2, pp. 42-48, 2009.

[46] R. Apiratikul and P. Pavasant, "Batch and column studies of biosorption of heavy metals by Caulerpa lentillifera," Bioresource Technology, vol. 99, no. 8, pp. 2766-2777, 2008.

[47] A. Saeed, M. Iqbal, and M. W. Akhtar, "Removal and recovery of lead(II) from single and multimetal ( $\mathrm{Cd}, \mathrm{Cu}, \mathrm{Ni}, \mathrm{Zn})$ solutions by crop milling waste (black gram husk)," Journal of Hazardous Materials, vol. 117, no. 1, pp. 65-73, 2005.

[48] H. J. Park, S. W. Jeong, J. K. Yang, B. G. Kim, and S. M. Lee, "Removal of heavy metals using waste eggshell," Journal of Environmental Sciences, vol. 19, no. 12, pp. 1436-1441, 2007. 
[49] Y. N. Mata, M. L. Blázquez, A. Ballester, F. González, and J. A. Muñoz, "Sugar-beet pulp pectin gels as biosorbent for heavy metals: preparation and determination of biosorption and desorption characteristics," Chemical Engineering Journal, vol. 150, no. 2-3, pp. 289-301, 2009.

[50] S. Schiewer and S. B. Patil, "Modeling the effect of $\mathrm{pH}$ on biosorption of heavy metals by citrus peels," Journal of Hazardous Materials, vol. 157, no. 1, pp. 8-17, 2008.

[51] G. Annadurai, R. S. Juang, and D. J. Lee, "Adsorption of heavy metals from water using banana and orange peels," Water Science and Technology, vol. 47, no. 1, pp. 185-190, 2003.

[52] B. Nasernejad, T. E. Zadeh, B. B. Pour, M. E. Bygi, and A. Zamani, "Camparison for biosorption modeling of heavy metals (Cr (III), Cu (II), Zn (II)) adsorption from wastewater by carrot residues," Process Biochemistry, vol. 40, no. 3-4, pp. 13191322, 2005.

[53] A. A. Abia, M. Horsfall Jr., and O. Didi, "The use of chemically modified and unmodified cassava waste for the removal of $\mathrm{Cd}$, $\mathrm{Cu}$ and $\mathrm{Zn}$ ions from aqueous solution," Bioresource Technology, vol. 90, no. 3, pp. 345-348, 2003.

[54] M. Horsfall Jr. and A. A. Abia, "Sorption of cadmium(II) and zinc(II) ions from aqueous solutions by cassava waste biomass (Manihot sculenta Cranz)," Water Research, vol. 37, no. 20, pp. 4913-4923, 2003.

[55] R. Apiratikul and P. Pavasant, "Sorption of $\mathrm{Cu}^{2+}, \mathrm{Cd}^{2+}$, and $\mathrm{Pb}^{2+}$ using modified zeolite from coal fly ash," Chemical Engineering Journal, vol. 144, no. 2, pp. 245-258, 2008.

[56] P. Pavasant, R. Apiratikul, V. Sungkhum, P. Suthiparinyanont, S. Wattanachira, and T. F. Marhaba, "Biosorption of $\mathrm{Cu}^{2+}, \mathrm{Cd}^{2+}$, $\mathrm{Pb}^{2+}$, and $\mathrm{Zn}^{2+}$ using dried marine green macroalga Caulerpa lentillifera," Bioresource Technology, vol. 97, no. 18, pp. 23212329, 2006.

[57] L. C. Ajjabi and L. Chouba, "Biosorption of $\mathrm{Cu}^{2+}$ and $\mathrm{Zn}^{2+}$ from aqueous solutions by dried marine green macroalga Chaetomorpha linum," Journal of Environmental Management, vol. 90, no. 11, pp. 3485-3489, 2009.

[58] M. Sciban, M. Klasnja, and B. Skrbic, "Modified hardwood sawdust as adsorbent of heavy metal ions from water," Wood Science and Technology, vol. 40, no. 3, pp. 217-227, 2006.

[59] M. Sciban, M. Klasnja, and B. Skrbic, "Modified softwood sawdust as adsorbent of heavy metal ions from water," Journal of Hazardous Materials, vol. 136, no. 2, pp. 266-271, 2006.

[60] S. K. Srivastava, A. K. Singh, and A. Sharma, "Studies on the uptake of lead and zinc by lignin obtained from black liquor-a paper industry waste material," Environmental Technology, vol. 15, no. 4, pp. 353-361, 1994.

[61] T. G. Chuah, A. Jumasiah, I. Azni, S. Katayon, and S. Y. Thomas Choong, "Rice husk as a potentially low-cost biosorbent for heavy metal and dye removal: an overview," Desalination, vol. 175, no. 3, pp. 305-316, 2005.

[62] K. K. Wong, C. K. Lee, K. S. Low, and M. J. Haron, "Removal of $\mathrm{Cu}$ and $\mathrm{Pb}$ by tartaric acid modified rice husk from aqueous solutions," Chemosphere, vol. 50, no. 1, pp. 23-28, 2003.

[63] S. F. Montanher, E. A. Oliveira, and M. C. Rollemberg, "Removal of metal ions from aqueous solutions by sorption onto rice bran," Journal of Hazardous Materials, vol. 117, no. 2-3, pp. 207-211, 2005.

[64] A. A. M. Daifullah, B. S. Girgis, and H. M. H. Gad, "Utilization of agro-residues (rice husk) in small waste water treatment plans," Materials Letters, vol. 57, no. 11, pp. 1723-1731, 2003.
[65] R. Joshi and R. Lothia, Fly Ash in Concrete: Production, Properties and Uses, vol. 2 of Advances in Concrete Technology, Gordon and Breach Science Publishers, 1997.

[66] N. Gangoli, D. Markey, and G. Thodos, "Removal of heavy metal ions from aqueous solutions with fly ash," in Proceedings of the National Conference on Complete Wateruse, pp. 270-275, Chicago, Ill, USA, May 1975.

[67] B. Bayat, "Combined removal of zinc (II) and cadmium (II) from aqueous solutions by adsorption onto high-calcium Turkish fly ash," Water, Air, and Soil Pollution, vol. 136, no. 1-4, pp. 69-92, 2002.

[68] B. Bayat, "Comparative study of adsorption properties of Turkish fly ashes: I. The case of nickel(II), copper(II) and zinc(II)," Journal of Hazardous Materials, vol. 95, no. 3, pp. 251-273, 2002.

[69] P. Ricou, I. Lécuyer, and P. Le Cloirec, "Removal of $\mathrm{Cu}^{2+}, \mathrm{Zn}^{2+}$ and $\mathrm{Pb}^{2+}$ adsorption onto fly ash and fly ash/lime mixing," Water Science and Technology, vol. 39, no. 10-11, pp. 239-247, 1999.

[70] P. Ricou-Hoeffer, I. Lecuyer, and P. Le Cloirec, "Experimental design methodology applied to adsorption of metallic ions onto fly ash," Water Research, vol. 35, no. 4, pp. 965-976, 2001.

[71] S. Rio, A. Delebarre, V. Héquet, P. Le Cloirec, and J. Blondin, "Metallic ion removal from aqueous solutions by fly ashes: multicomponent studies," Journal of Chemical Technology and Biotechnology, vol. 77, no. 3, pp. 382-388, 2002.

[72] V. K. Gupta and I. Ali, "Utilisation of bagasse fly ash (a sugar industry waste) for the removal of copper and zinc from wastewater," Separation and Purification Technology, vol. 18, no. 2, pp. 131-140, 2000.

[73] V. K. Gupta and S. Sharma, "Removal of zinc from aqueous solutions using bagasse fly ash-a low cost adsorbent," Industrial and Engineering Chemistry Research, vol. 42, no. 25, pp. 66196624, 2003.

[74] D. Batabyal, A. Sahu, and S. K. Chaudhuri, "Kinetics and mechanism of removal of 2, 4-dimethyl phenol from aqueous solutions with coal fly ash," Separations Technology, vol. 5, no. 4, pp. 179-186, 1995.

[75] J. Kumar, C. Balomajumder, and P. Mondal, "Application of agro-based biomasses for zinc removal from wastewater-a review," Clean-Soil, Air, Water, vol. 39, no. 7, pp. 641-652, 2011.

[76] G. Kyzas and M. Kostoglou, "Green adsorbents for wastewaters: a critical review," Materials, vol. 7, no. 1, pp. 333-364, 2014.

[77] R. C. Bansal and M. Goyal, Activated Carbon Adsorption, Taylor \& Francis, Boca Raton, Fla, USA, 2005.

[78] A. Chojnacki, K. Chojnacka, J. Hoffmann, and H. Górecki, "The application of natural zeolites for mercury removal: from laboratory tests to industrial scale," Minerals Engineering, vol. 17, no. 7-8, pp. 933-937, 2004.

[79] Z. Aksu, "Application of biosorption for the removal of organic pollutants: a review," Process Biochemistry, vol. 40, no. 3-4, pp. 997-1026, 2005.

[80] A. A. Duarte, M. A. Martins, and P. J. Ramísio, "Assessment of dissolved zinc removal using new sorbent materials," in Proceeding of the $3 \mathrm{rd}$ International Conference on Development, Energy, Environment, Economics (DEEE '12), pp. 101-106, Paris, France, 2012.

[81] A. A. L. S. Duarte, S. J. A. Cardoso, and A. J. Alçada, "Emerging and innovative techniques for arsenic removal applied to a small water supply system," Sustainability, vol. 1, no. 4, pp. 1288-1304, 2009. 
[82] P. J. Cyr, R. P. S. Suri, and E. D. Helmig, "A pilot scale evaluation of removal of mercury from pharmaceutical wastewater using granular activated carbon," Water Research, vol. 36, no. 19, pp. 4725-4734, 2002.

[83] P. J. Ramísio and J. M. P. Vieira, "Heavy metal removal efficiency in a kaolinite-sand media filtration pilot-scale installation," in Highway and Urban Environment, G. Morrison and S. Rauch, Eds., Alliance For Global Sustainability Bookseries, pp. 319-329, Springer, Dordrecht, The Netherlands, 2007.

[84] J. L. Conca and J. Wright, "An Apatite II permeable reactive barrier to remediate groundwater containing $\mathrm{Zn}, \mathrm{Pb}$ and $\mathrm{Cd}$," Applied Geochemistry, vol. 21, no. 8, pp. 1288-1300, 2006.

[85] J. Wang and C. Chen, "Biosorbents for heavy metals removal and their future," Biotechnology Advances, vol. 27, no. 2, pp. 195226, 2009.

[86] R. M. Recovery, http://www.clu-in.org/products/site/complete /resource.htm.

[87] W. M. Mayes, H. A. B. Potter, and A. P. Jarvis, "Novel approach to zinc removal from circum-neutral mine waters using pelletised recovered hydrous ferric oxide," Journal of Hazardous Materials, vol. 162, no. 1, pp. 512-520, 2009.

[88] G. Garnham, J. Wase, and C. Forster, "The use of algae as metal biosorbents," in Biosorbents For Metal Ions, pp. 11-37, CRC Press, London, UK, 1997.

[89] K. H. Chu and M. A. Hashim, "Adsorption and desorption characteristics of zinc on ash particles derived from oil palm waste," Journal of Chemical Technology and Biotechnology, vol. 77, no. 6, pp. 685-693, 2002.

[90] S. Chakravarty, S. Bhattacharjee, K. K. Gupta, M. Singh, H. T. Chaturvedi, and S. Maity, "Adsorption of zinc from aqueous solution using chemically treated newspaper pulp," Bioresource Technology, vol. 98, no. 16, pp. 3136-3141, 2007.

[91] P. C. Mishra and R. K. Patel, "Removal of lead and zinc ions from water by low cost adsorbents," Journal of Hazardous Materials, vol. 168, no. 1, pp. 319-325, 2009.

[92] Y. Zhang, Y. Li, L.-Q. Yang, X.-J. Ma, L.-Y. Wang, and Z.-F. Ye, "Characterization and adsorption mechanism of $\mathrm{Zn}^{2+}$ removal by PVA/EDTA resin in polluted water," Journal of Hazardous Materials, vol. 178, no. 1-3, pp. 1046-1054, 2010.

[93] Y. Miyake, "The soil purifying method that combine soil vapor extraction and activated carbon fiber," Journal of Resources and Environment, vol. 33, pp. 896-899, 1998.

[94] M. Ncube and Y. Su, "The removal of volatile organic compounds from supply air using a desiccant column - a theoretical study," International Journal of Sustainable Built Environment, vol. 1, no. 2, pp. 259-268, 2012.

[95] A. Mellah and S. Chegrouche, "The removal of zinc from aqueous solutions by natural bentonite," Water Research, vol. 31, no. 3, pp. 621-629, 1997.

[96] S. S. Banerjee, R. V. Jayaram, and M. V. Joshi, "Removal of nickel(II) and zinc(II) from wastewater using fly ash and impregnated fly ash," Separation Science and Technology, vol. 38, no. 5, pp. 1015-1032, 2003.

[97] H. M. Zwain and I. Dahlan, "Characterization of RHA /PFA/CFA adsorbent and its equilibrium and kinetic studies for $\mathrm{Zn}^{2+}$ removal," Caspian Journal of Applied Sciences Research, vol. 1, no. 13, pp. 23-34, 2012. 

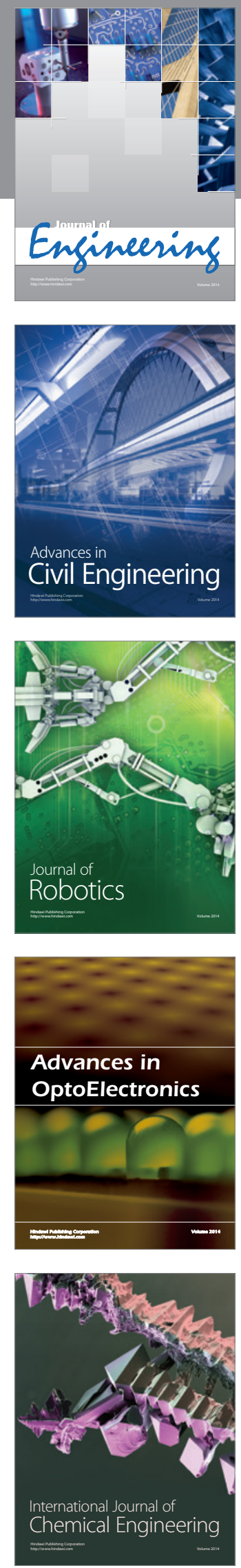

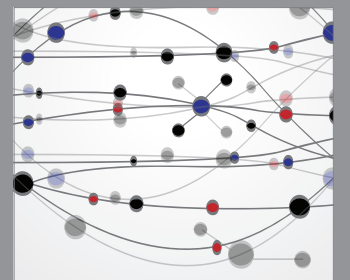

The Scientific World Journal
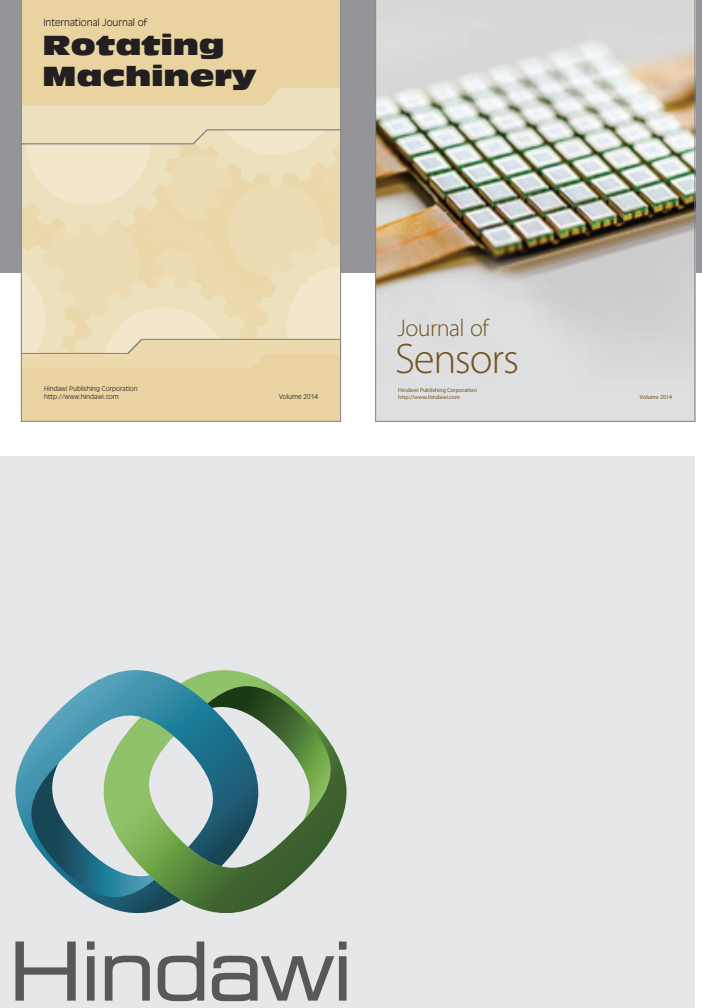

Submit your manuscripts at http://www.hindawi.com
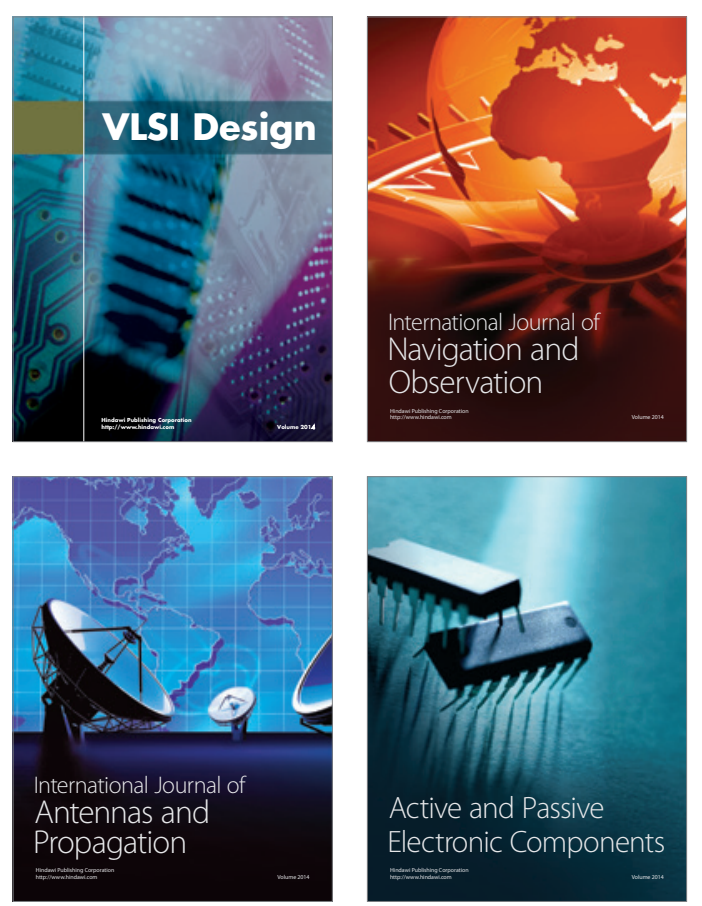
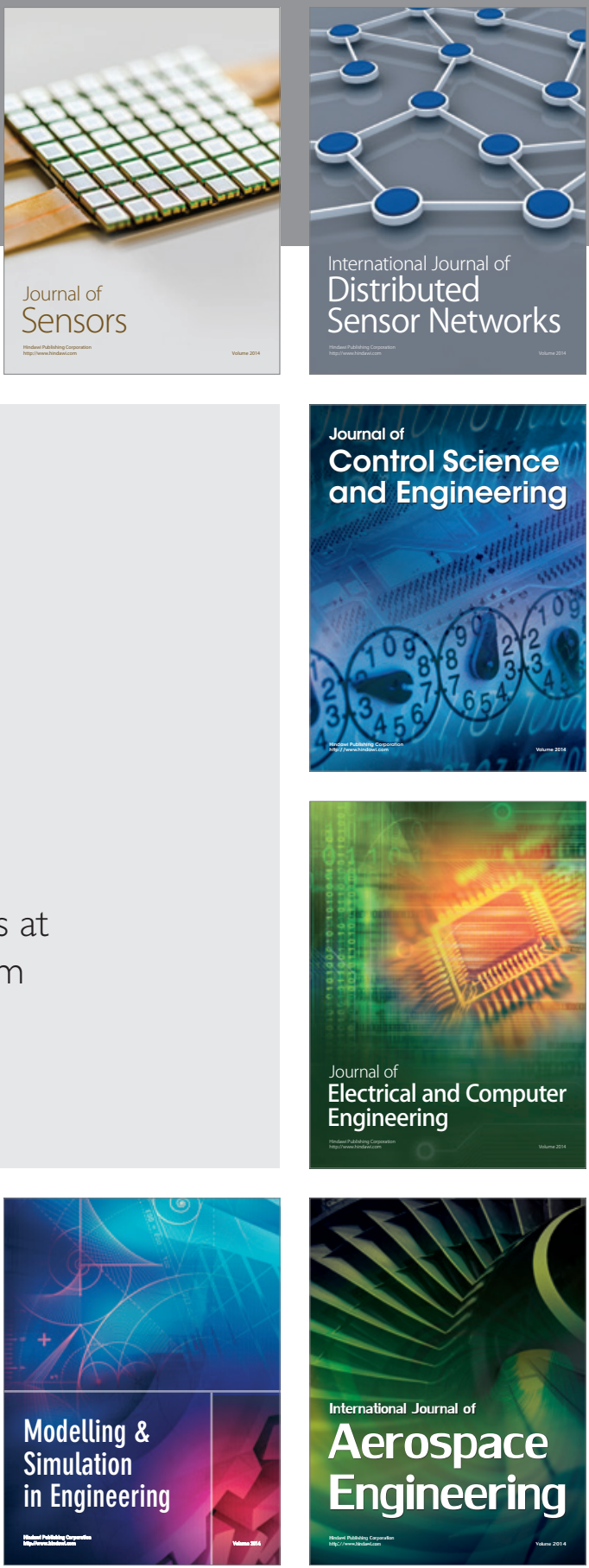

Journal of

Control Science

and Engineering
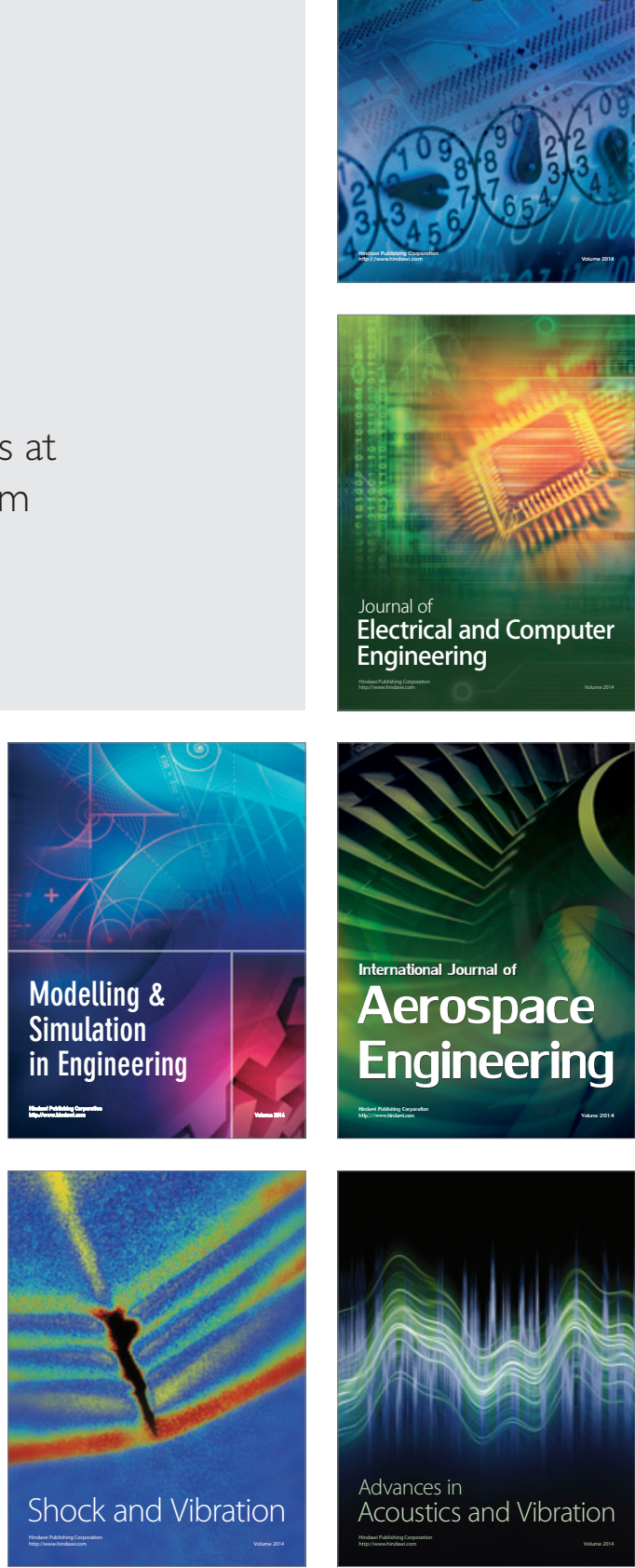